\title{
Renal Cell Carcinoma in the Allograft: What Is the Role of Polyomavirus?
}

\author{
Valerie Neirynck ${ }^{a} \quad K^{2}$ athleen Claes ${ }^{a} \quad$ Maarten Naesens ${ }^{a}$ \\ Liesbeth De Wever $^{b}$ Jacques Pirenne ${ }^{d}$ Dirk Kuypers ${ }^{a}$ \\ Yves Vanrenterghem ${ }^{a}$ Hendrik Van Poppel $^{\mathrm{e}}$ \\ Andre Kabanda ${ }^{f}$ Evelyne Lerut ${ }^{c}$ \\ Departments of ${ }^{\mathrm{a}}$ Nephrology and Renal Transplantation, ${ }^{\mathrm{b}}$ Radiology,

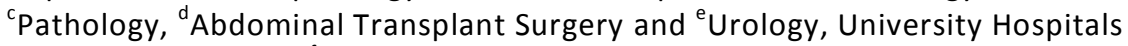 \\ Leuven, Leuven, and ${ }^{f}$ Department of Nephrology, Edith Cavell Hospital, \\ Brussels, Belgium
}

\section{Key Words}

BK virus $\cdot$ Polyoma $\cdot$ Renal cell carcinoma $\cdot$ Kidney transplant

\begin{abstract}
$B K$ virus (BKV) is known to cause subclinical infection in childhood. The virus remains latent in the human body, mainly in the urinary tract epithelium. After initiation of an immunosuppressive treatment, reactivation can occur in renal transplant recipients. BKV can cause hemorrhagic cystitis, ureteral stenosis and BKV nephropathy in immunocompromised patients. Furthermore, a number of case reports suggest an association between BKV infection and the development of urinary tract cancer. So far, an oncogenic potential of BKV has been observed in vitro and in animal models; however, its oncogenic capacity in humans remains unclear. We report the case of a 59-year-old patient who developed a poorly differentiated renal cell carcinoma in her renal allograft, with pulmonary and abdominal metastasis. Surgical removal of the allograft and cessation of the immunosuppressive therapy resulted in complete resolution of the metastatic disease.
\end{abstract}

\section{Introduction}

BK virus (BKV; polyomavirus hominis 1) is a member of the Polyomaviridae family and was named according to the initials (B.K.) of the first patient it was isolated from [1]. After virion uptake by a susceptible host, BKV genomes, circular double-stranded DNA of 5,300 base pairs, are incorporated in the host nucleus. BKV is known to cause 
clinically insignificant infections (asymptomatic or upper respiratory tract infection/flu-like symptoms) in childhood. After this primo-infection, the virus remains latent in the human body, mainly in the epithelium of the urinary tract. Although the natural transmission route in humans has not yet been established, $75-90 \%$ of the adults worldwide are BKV seropositive [2-4]. Symptomatic BKV infections can occur in immunocompromised patients and cause disease with clinical signs. Over the last decades, concurrent with the introduction of more potent immunosuppressive therapies, BKV gained recognition because of the graft nephropathy (BKVN) it can cause after reactivation of the virus in immunodeficient patients [5]. Nowadays, BKVN occurs on average 1 year after transplantation in 1-9\% of all renal transplant patients. With a risk of graft failure of $30-60 \%$, it is one of the most important complications after transplantation $[2,4,5]$. In most patients with BKVN, the level of viremia is in the range of $10^{6}$ copies $/ \mathrm{ml}$, whereas in the asymptomatic renal allograft recipients, viremia levels $<10^{3}$ copies $/ \mathrm{ml}$ have been described in $92 \%$ of the cases [6]. Awareness for those levels is the first step in the diagnosis of possible BKVN, especially with deteriorating renal function. Although those viremia levels are useful as a marker in the follow-up of kidney allograft patients, the diagnosis of BKVN can only be made on renal biopsy; based on the typical cytopathic changes (intranuclear viral inclusions) of the tubular epithelium, on a positive immunohistochemical staining with antibody against SV40 large $\mathrm{T}$ antigen together with signs of interstitial inflammation and/or resulting scarring of the graft. Treatment of biopsy-proven BKVN consists primarily in reduction of the immunosuppressive medication, while in some circumstances, adjuvant antiviral therapy with cidofovir or leflunomide can also improve the outcome of BKVN.

Besides the correlation between BKVN and graft failure, a small number of case reports suggest an association between BKV infection and the development of renal and bladder cancers in renal transplant recipients [7-14] (table 1). Indeed, for more than 30 years, an oncogenic potential of BKV has been observed in vitro and in animal models $[3,15,16]$. In humans, however, the implication of BKV in tumour development is still unclear.

It is well known that the risk of malignancy is increased in case of immunosuppression. It has been hypothesized that withdrawal of the immunosuppression in case of a de novo tumour after transplantation might cause a tumour rejection due to recovery of the patient's immune system. This strategy seemed successful in individual cases, although the literature data are limited $[8,17]$.

We present a patient with metastasized, high-grade BKV-related renal cell carcinoma (RCC) in her renal allograft. Transplantectomy and discontinuation of immunosuppressive medication resulted in a spontaneous disappearance of the metastases, which strengthens the hypothesis that in individual cases, a direct correlation can be present between tumour and viral infection.

\section{Case Report}

A 57-year-old female patient of African origin with a history of end-stage renal disease due to primary glomerulonephritis and deceased donor kidney transplantation presented 5 years after transplantation with sudden onset of nephrotic range proteinuria and microscopic haematuria. Her immunosuppressive regimen consisted of tacrolimus (Prograft ${ }^{\circledR}$, target predose trough levels 8-10 $\mathrm{ng} / \mathrm{l}$ ), mycophenolate mofetil (Cellcept ${ }^{\circledR}, 0.75 \mathrm{~g} /$ day) and methylprednisolone $\left(\right.$ Medrol $^{\circledR}, 4 \mathrm{mg} /$ day) . 
She suffered from episodes of severe diarrhoea during the last 2 years, which led to a weight loss of $15.9 \mathrm{~kg}$, despite a lactose-free diet and mycophenolate mofetil dose reduction.

Except for some crepitations in the lower lobe of the left lung, clinical examination revealed no abnormalities. Her renal allograft function was stable (serum creatinine $1.55 \mathrm{mg} / \mathrm{dl}$ and MDRD eGFR $42 \mathrm{ml} / \mathrm{min} / 1.73 \mathrm{~m}^{2}$ ). A renal allograft biopsy showed minimal interstitial fibrosis and tubular atrophy (Banff grade Ib). Due to the striped appearance of the atrophy, the presence of capsular fibrosis and (sometimes nodular) arteriolar hyalinosis, the suggestion of chronic calcineurin inhibitor toxicity was made (fig. 1). No features of acute cellular or antibody-mediated rejection, (viral) infection, or amyloidosis were detected. On a CT scan, hepatomegaly with multiple mesenterial lymphadenopathies was detected, which led to a tentative clinical diagnosis of posttransplant lymphoproliferative disorder. However, histological examination of a liver biopsy, a lymph node and bone marrow sample could not reveal any features of malignancy, neither did a PET-CT scan show any pathological metabolic active lesions. The findings on RX transit of the small intestine were nonspecific. Neither radiologic examination nor endoscopy nor biochemistry could retain positive arguments for coeliac disease. Faecal cultures were repeatedly negative. The patient remained on triple immunosuppression, but with a dose reduction (tacrolimus target predose trough levels 6-8 $\mathrm{ng} / \mathrm{l}$, mycophenolate mofetil $500 \mathrm{mg} /$ day and methylprednisolone $8 \mathrm{mg} /$ day).

After these modifications, there was a decrease in proteinuria and the allograft function recovered and remained stable. The patient also regained some weight. No new clinical findings developed during follow-up via the outpatient clinic.

Two years later, the patient was readmitted because of weight loss and iron deficiency anaemia. Gastrointestinal work-up showed no lesions suspicious for recent bleeding. Her renal function was stable at the time (serum creatinine $1.69 \mathrm{mg} / \mathrm{dl}$ ), but ultrasound examination and a PET-CT scan of the allograft revealed a tumour mass with a maximal diameter of $7 \mathrm{~cm}$, interpolar and extending to the lower pole of the allograft ( $\underline{\text { fig. } 2}$ a), accompanied by two lymphadenopathies (one posterior to the right external iliac artery and another one nearby the right arteria iliaca communis, $3.3 \mathrm{~cm}$ in diameter) and several bilateral lung metastases (11-12 $\mathrm{mm}$ in diameter; fig. 2b). A transcutaneous needle biopsy of the mass showed a high-grade carcinoma, difficult to subtype based on the morphology and immunohistochemical profile of the tumour cells. It was decided to stop all immunosuppressive agents and to perform a transplantectomy. Surgical removal of the metastases seemed not realistic due to the extent of the metastatic spread.

Histopathological examination of the transplantectomy specimen showed a tumour of $8 \mathrm{~cm}$ in size, which was demarcated from the surrounding parenchyma in several areas. In other areas, however, the tumour infiltrated the renal parenchyma. The growth patterns of the tumour were solid sheets, nests and strands, and the tumour showed a very high degree of cytological and nuclear atypia. Both typical and atypical mitotic figures were numerous. The tumour displayed immunohistochemical positivity for CD10/CK7/CK19, and was negative for 34betaE12/Ulex europaeus lectin (fig. 3). Based on morphology and immunohistochemistry, the diagnosis of a high-grade, poorly differentiated RCC, Fuhrmann grade IV, was made. The ureteral urothelium was tumour-free, although anisokaryosis with the impression of viral inclusions was conspicuous. Subsequent SV40 (monoclonal anti-SV40 T Antigen (Ab-2), dilution 1/40; Calbiochem, Germany; automatical immunohistochemical staining in Dako Autostainer Link 48 after automatical antigen retrieval $(\mathrm{pH}=9)$ in Dako PT Link (Dako, Denmark)) stained positive in the urothelium as well as in the tumour and the surrounding nontumoural renal parenchyma (fig. $4 \mathrm{a}, \mathrm{b}$ ). In the tumour, $65-70 \%$ of the neoplastic cells showed moderate to strong SV40 positivity, compared to the nontumo ural surrounding tissue, where only a minority $(<1 \%)$ of the tubular cells displayed SV40 positivity both in the cortex and medulla. Remarkably, in the majority ( $90 \%$ ) of the tumour cells, both cytoplasm and nuclei stained positive for SV40, while in the surrounding nontumoural parenchyma - as in other cases of BKVN - only nuclear positivity was observed. In retrospect, the allograft biopsy conducted 2 years earlier was reviewed and stained for SV40. No cytopathic features of BKVN could be detected, but the SV40 stained positive in the nuclei of histologically normal tubular epithelial cells (fig. 4c). DNA analysis of the tumoural tissue showed mixed chimerism of donor and receptor cells.

Two years after cessation of the immunosuppressive therapy and transplantectomy, all metastatic localizations had disappeared on a CT scan (fig. 5). The patient, who returned to dialysis after the transplantectomy, is in good condition without any evidence of recurrent malignant disease. 


\section{Discussion}

We report the case of a 59-year-old African patient who developed a poorly differentiated, SV40-positive RCC in her allograft, with locoregional lymphadenopathies and pulmonary metastases. Surgical removal of the primary tumour and cessation of the immunosuppressive therapy resulted in complete resolution of the metastatic disease. The positive SV40 stain in the cytoplasm and nuclei of the tumour, adjacent urothelium and renal allograft tissue, and positive immunohistochemistry of SV40 in a prior renal allograft biopsy suggest that BKV plays a role in the occurrence of this malignant process. Moreover, the difference in the intracellular distribution of SV40 positivity between tumour cells (intracytoplasmic and intranuclear) and tubular epithelial cells in BKVN (only intranuclear staining) suggests that the malignant transformation could be related to intracellular redistribution of BKV large T antigen.

Other authors also suggested an association between polyomavirus replication/reactivation and cancer (table 1). First, Kausman et al. [8] described a paediatric case of de novo RCC in the allograft 3 years after transplantation. In the early period after transplantation, immunosuppressive therapy had been increased because of rejection. Subsequently, the patient developed BKVN, which was treated with reduction of immunosuppressive treatment. Three years later, the patient developed a poorly differentiated adenocarcinoma in his allograft. The authors hypothesized that after the episode of BKVN, BKV DNA had been incorporated in the host genome, which subsequently induced carcinogenesis. They suggested that the underlying mechanism for this process would be the binding of the large $\mathrm{T}$ antigen to intracellular proteins such as the tumour suppression protein $\mathrm{p} 53$, leading to increased viral replication and immortalization of the host cell. In animal models, indeed, this mechanism has been associated with the development of renal carcinomas and neuroblastomas [15-17]. However, Kausman et al. [8] could not confirm this hypothesis. Second, Narayanan et al. [9] described an adult case of metastasized RCC in a 40-year-old renal transplant recipient, associated with BKV with a positive SV40 stain of both the primary and the metastatic tumour. They were the first to show BKV positivity within the cancer cells, which strengthened the earlier hypothesis of Kausman et al. [8].

Finally, not only RCCs have been suggested to be associated with BKV, also case reports on BKV-associated urothelial carcinoma have been published [7, 12, 13]. That both renal parenchyma and urothelium are predilection sites for the development of BKV-associated malignancies may not surprise as the urinary tract is the homing site for BKV after primary infection.

Our case and the case previously reported by Kausman et al. [8] are the only two cases where surgical removal of the primary tumour and cessation of the immunosuppressive therapy led to complete remission of the malignant process and disappearance of its metastatic localizations. We hypothesize that the removal of the tumour and restoring the recipient's immune system leads to a rejection of any remaining tumour cells in the patient. Similar responses were observed in immunocompetent patients, supporting the hypothesis that the human immune system can reject remaining metastatic tumour cells [18-20]. Further research is necessary to establish in which cases this strategy could be successful and whether SV40 positivity could be used as a biomarker for treatment decision and prognosis. 


\section{Conclusion}

In conclusion, we report a case of a 59-year-old African patient who developed a poorly differentiated, SV40-positive RCC in her allograft. At the time of diagnosis, the tumour had disseminated to locoregional lymph nodes and both lungs. Surgical removal of the primary tumour and cessation of the immunosuppression resulted in complete resolution of the metastatic disease. The patient returned to dialysis and is currently in good condition. Further research is needed to assess the frequency of BKVrelated malignancies in immunocompromised patients to study the mechanism of malignant transformation of tubular epithelium by BKV in humans.

Table 1. Comprehensive overview of the literature of BKV-associated renal and urothelial carcinoma in renal allograft patients

\begin{tabular}{|c|c|c|c|c|c|c|c|c|}
\hline Study & $\begin{array}{l}\text { Case } \\
\text { No. }\end{array}$ & Sex & $\begin{array}{l}\text { Age } \\
\text { years }\end{array}$ & Tx type & $\begin{array}{l}\text { Time since } \mathrm{Tx} \\
\text { years }\end{array}$ & Histology & Therapy & $\begin{array}{l}\text { Outcome } \\
\text { (years of } \\
\text { follow-up) }\end{array}$ \\
\hline $\begin{array}{l}\text { Current } \\
\text { case report }\end{array}$ & 1 & $\mathrm{~F}$ & 57 & kidney & 7 & RCC, Fuhrman IV & $\begin{array}{l}\text { cessation of IS, } \\
\text { transplantectomy }\end{array}$ & $\operatorname{good}(5)$ \\
\hline $\begin{array}{l}\text { Geetha et al. } \\
\text { [7] }\end{array}$ & 2 & M & 58 & $\begin{array}{l}\text { kidney/ } \\
\text { pancreas }\end{array}$ & 4 & $\begin{array}{l}\text { TCC bladder, } \\
\text { bone metastasis }\end{array}$ & $\begin{array}{l}\text { reduction of IS, } \\
\text { TURB, RT }\end{array}$ & deceased \\
\hline $\begin{array}{l}\text { Kausman et al. } \\
{[8]}\end{array}$ & 3 & M & 10 & kidney & $\begin{array}{l}3 \text { years } \\
10 \text { months }\end{array}$ & $\begin{array}{l}\text { kidney, poorly } \\
\text { differentiated adenoca }\end{array}$ & $\begin{array}{l}\text { cessation of IS, } \\
\text { transplantectomy, } \\
\text { debulking }\end{array}$ & $\operatorname{good}(1)$ \\
\hline $\begin{array}{l}\text { Narayanan et al. } \\
\text { [9] }\end{array}$ & 4 & M & 40 & $\begin{array}{l}\text { kidney/ } \\
\text { pancreas }\end{array}$ & 5 & RCC, high-grade & $\begin{array}{l}\text { transplantectomy } \\
+ \text { switch to sirolimus } \\
\text { and prednisolone }\end{array}$ & $\operatorname{good}(2.5)$ \\
\hline $\begin{array}{l}\text { Galed-Placed and } \\
\text { Valbuena-Ruvira } \\
{[10]}\end{array}$ & 5 & $\mathrm{~F}$ & 38 & $\begin{array}{l}\text { kidney/ } \\
\text { pancreas }\end{array}$ & 6 & TCC bladder & NR & NR \\
\hline $\begin{array}{l}\text { Emerson et al. } \\
\text { [11] }\end{array}$ & 6 & M & 6.5 & kidney & 3.5 & $\begin{array}{l}\text { collecting duct } \\
\text { carcinoma }\end{array}$ & $\begin{array}{l}\text { cessation of IS, } \\
\text { transplantectomy }\end{array}$ & NR \\
\hline $\begin{array}{l}\text { Roberts et al. } \\
{[12]}\end{array}$ & 7 & $\mathrm{~F}$ & 40 & kidney & 4 & TCC bladder, T3 & $\begin{array}{l}\text { cystectomy, } \\
\text { bilateral NUx } \\
\text { + hysterectomy }\end{array}$ & $\operatorname{good}(6)$ \\
\hline \multirow[t]{3}{*}{$\begin{array}{l}\text { Wang et al. } \\
{[13]}\end{array}$} & 8 & M & 54 & kidney & 3 & TCC, Ta & $\begin{array}{l}\text { bilateral native NUx } \\
\text { + TURB + switch } \\
\text { to sirolimus }\end{array}$ & good \\
\hline & 9 & M & 26 & kidney & 3 months & $\begin{array}{l}\text { TC (bladder T1 } \\
+\mathrm{R} \text { pyelym T3) }\end{array}$ & $\begin{array}{l}\text { left native NUx + TURB } \\
+ \text { switch to sirolimus }\end{array}$ & recurrence \\
\hline & 10 & M & 55 & kidney & 3 & $\begin{array}{l}\text { TCC (ureter T2 } \\
+ \text { renal Ta + bladder T1) }\end{array}$ & NR & good \\
\hline \multirow{3}{*}{$\begin{array}{l}\text { Chen et al. } \\
\text { [14] }\end{array}$} & 11 & NR & NR & kidney & $1.6-6.9$ & TCC & NR & NR \\
\hline & 12 & NR & NR & kidney & $1.6-6.9$ & TCC & NR & NR \\
\hline & 13 & NR & NR & kidney & $1.6-6.9$ & TCC & NR & NR \\
\hline
\end{tabular}

$\mathrm{Tx}=$ Transplantation; $\mathrm{IS}$ = immunosuppression; $\mathrm{TCC}$ = transitional cell carcinoma; TURB = transurethral resection of the bladder; RT = radiotherapy; $\mathrm{NR}=$ not reported; $\mathrm{NUx}=$ nephroureterectomy. 


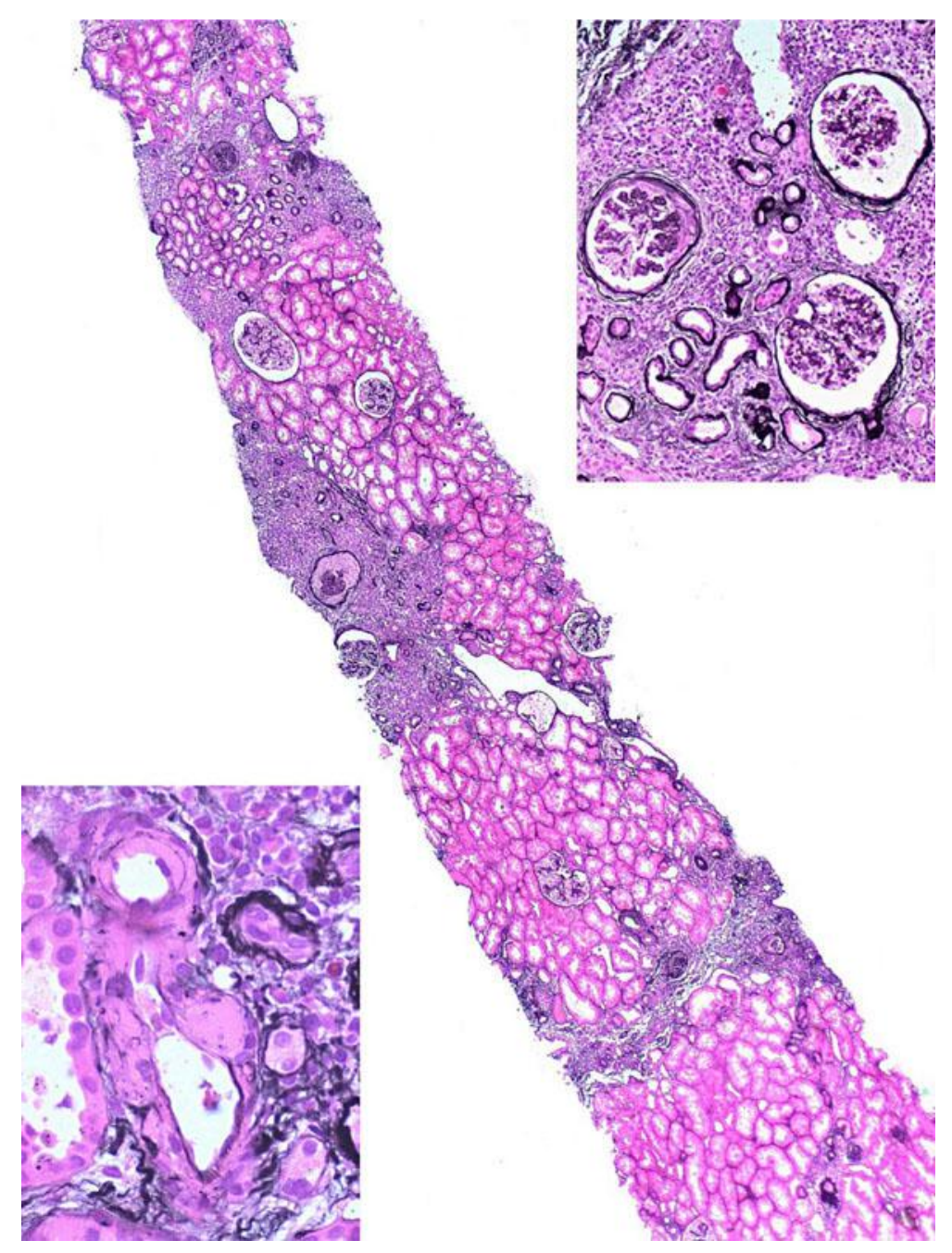

Fig. 1. In a renal allograft biopsy taken 2 years after transplantation, no features of acute rejection or viral infection were noted. The parenchyma showed striped atrophy, arteriolar hyalinosis (lower inset) and fibrosis of Bowman's capsule (upper inset), which led to the suggestion of chronic calcineurin inhibitor toxicity. Silver methenamine stain, original magnification $\times 25$, lower inset $\times 400$, upper inset $\times 100$. 

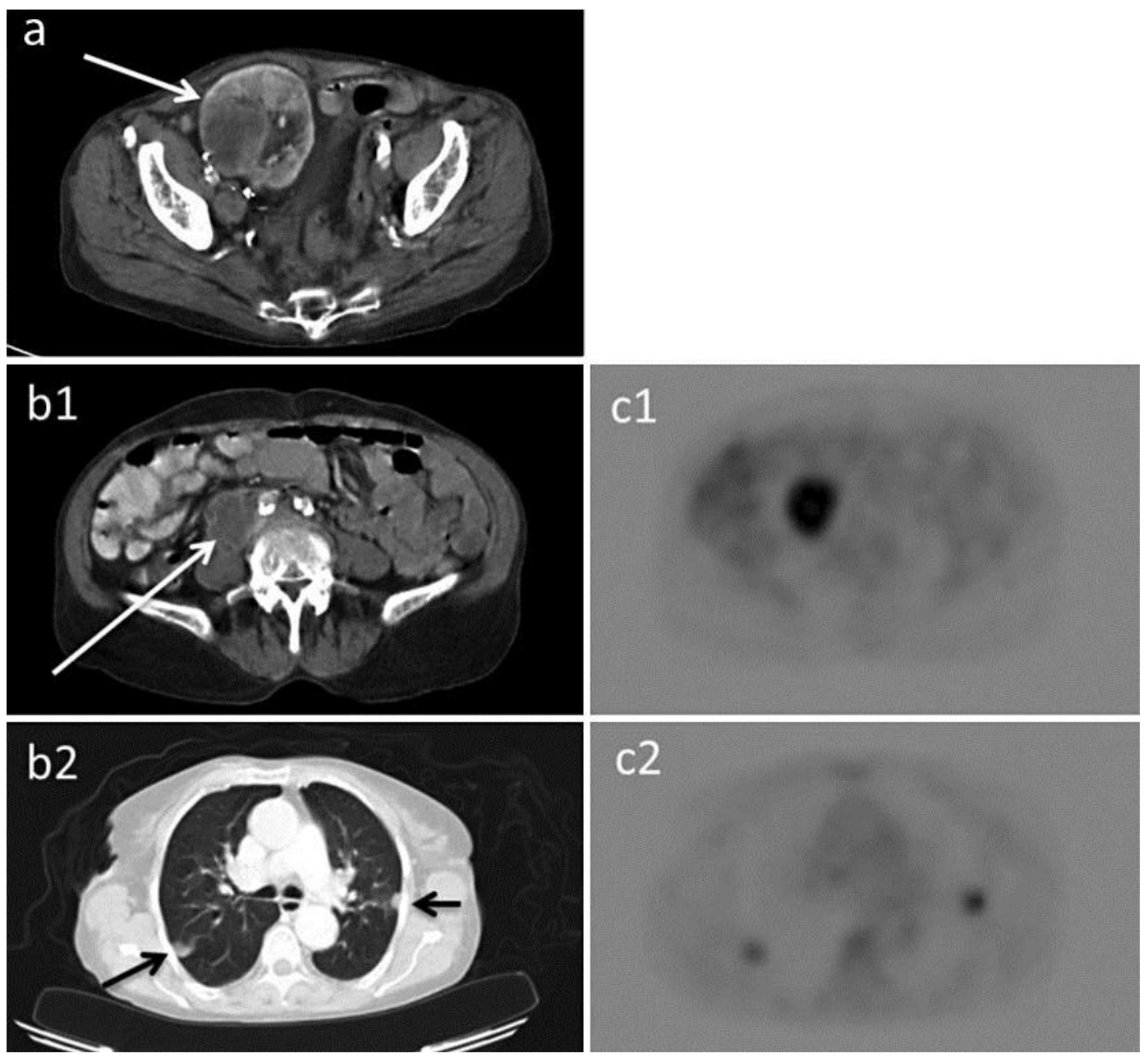

Fig. 2. a CT image of the RCC in the allograft showing a voluminous renal tumour, type RCC, bulging out in the renal pelvis and with necrosis within the tumoural mass, accompanied by a lymphadenopathy posterior to the right external iliac artery. b CT image of the necrotic adenopathy near the right arteria iliaca communis (b1), and two pulmonary metastases, right dorsobasal and left lateral (b2). c The primary kidney tumour as well as the necrotic adenopathy (c1) and lung metastasis (c2) are readily seen on the correlating PET images as hypermetabolic foci (hot spots). 


\section{Case Reports in Nephrology and
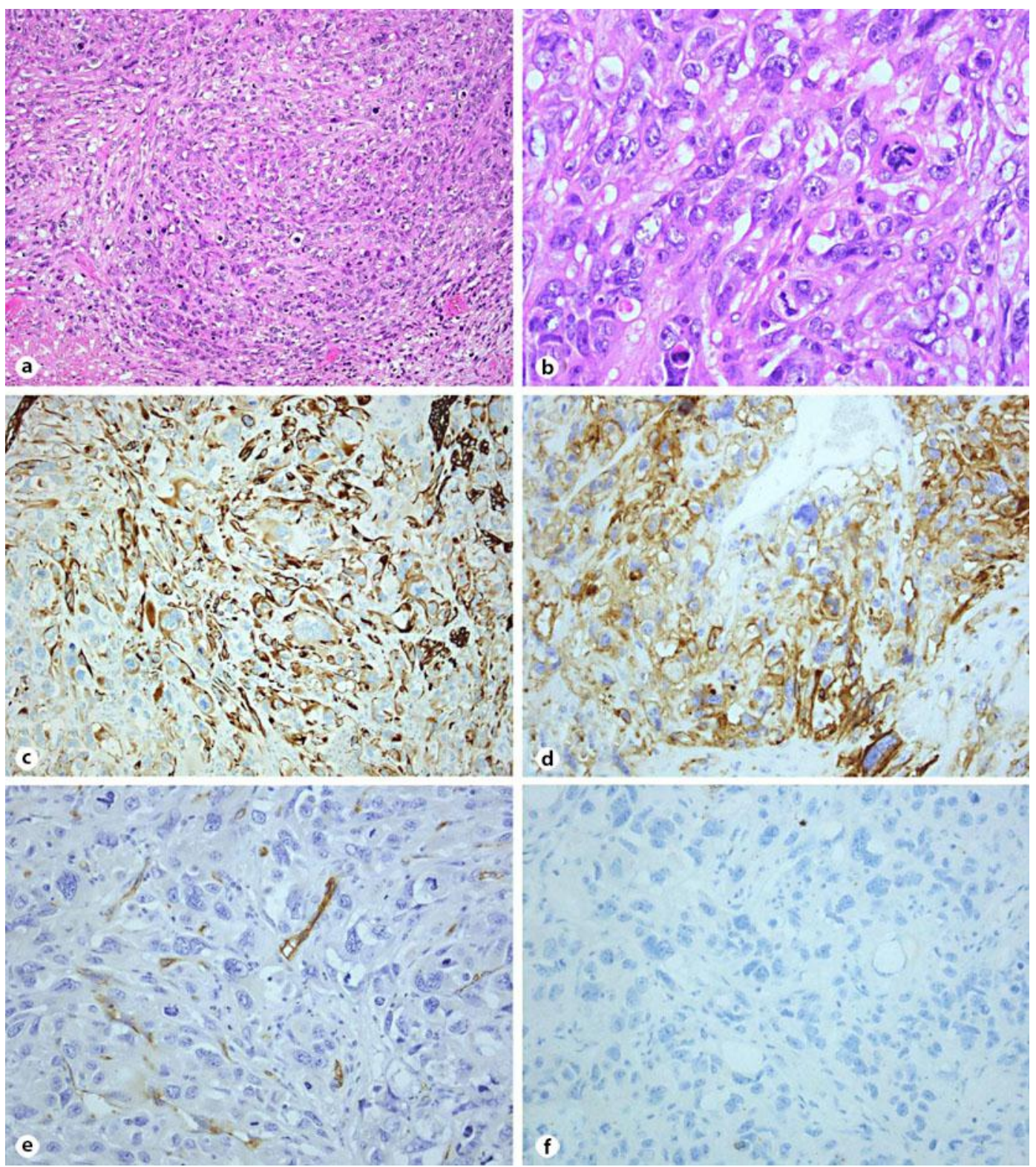

Fig. 3. a, b The tumour consisted mainly of solid sheets and strands, consisting of large, highly pleiomorphic cells. Note the marked nuclear atypia and brisk mitotic activity. HE stain, original magnification $\times 100(a), \times 400$ (b). c-f The tumour displays strong and diffuse positivity for CK7 (c) and CD10 (d), but is negative for Ulex europaeus lectin (e) en 34BE12 (f). Original magnification $\times 100$ (c), $\times 200(d-f)$. 

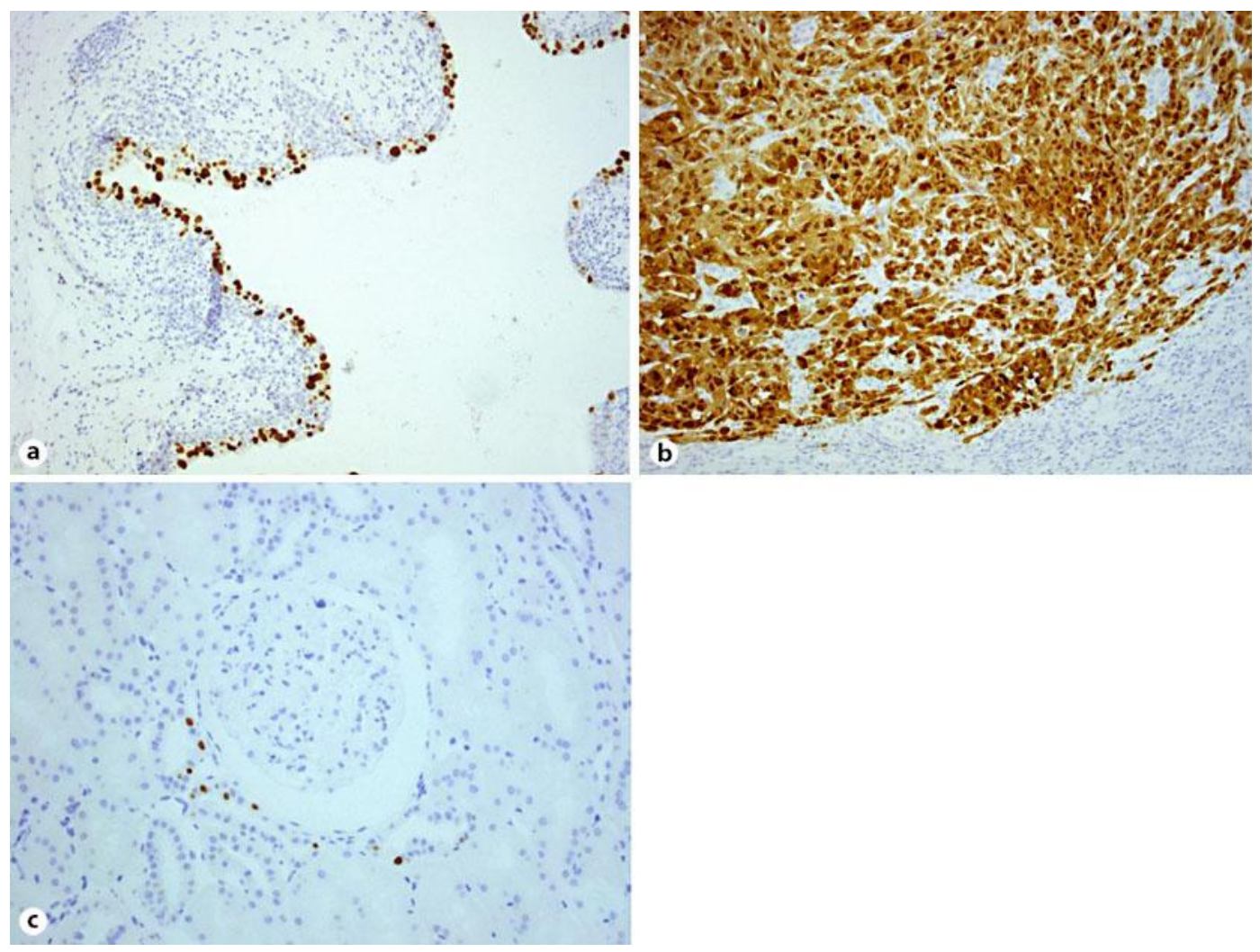

Fig. 4. SV40 positivity in the urothelium (a) and tumour (b) in the transplantectomy specimen. c SV40 positivity in the tubular epithelium of the allograft biopsy taken 5 years after transplantation. This biopsy was stained retrospectively (after the findings in the tumour) as no morphological evidence suggesting a viral infection was seen at the first reading of the needle biopsy. Note the nuclear staining in nontumoural cells (urothelium (a) tubular epithelium (c)) in contrast to the both cytoplasmic and nuclear SV40 positivity in almost all tumour cells (b). Original magnification $\times 100$ (a, b), $\times 200($ c).

\section{References}

1 Gardner SD, Field AM, Coleman DV, Hulme B: New human papovavirus (BK) isolated from urine after transplantation. Lancet 1971;1:1253-1257.

-2 Hirsch HH, Steiger J: Polyomavirus BK. Lancet Infect Dis 2003;3:611-623.

-3 Abend JR, Jiang M, Imperiale MJ: BK virus and human cancer: innocent until proven guilty. Semin Cancer Biol 2009;19:252-260.

4 Hariharan S: BK virus nephritis after renal transplantation. Kidney Int 2006;69:655-662.

5 Nickeleit V, Mihatsch MJ: Polyomavirus nephropathy in native kidneys and renal allografts: an update on an escalating threat. Transpl Int 2006;19:960-973.

6 Chan G, Leung A, Wong A, Chan K, Kwong Y, Lai K, Tang S: Quantification of BK viral load in asymptomatic renal allograft recipients. Ren Fail 2012;34:550-554.

7 Geetha D, Tong BC, Racusen L, Markowitz JS, Westra WH: Bladder carcinoma in a transplant recipient: evidence to implicate the BK human polyomavirus as a causal transforming agent. Transplantation 2002;73:1933-1936.

-8 Kausman JY, Somers GR, Francis DM, Jones CL: Association of renal adenocarcinoma and BK virus nephropathy post transplantation. Pediatr Nephrol 2004;19:459-462. 
9 Narayanan M, Szymanski J, Slavcheva E, Rao A, Kelly A, Jones K, Jaffers G: BK virus associated renal cell carcinoma: case presentation with optimized PCR and other diagnostic tests. Am J Transplant 2007;7:1666-1671.

10 Galed-Placed I, Valbuena-Ruvira L: Decoy cells and malignant cells coexisting in the urine from a transplant recipient with BK virus nephropathy and bladder adenocarcinoma. Diagn Cytopathol 2011;39:933-937.

11 Emerson LL, Carney HM, Layfield LJ, Sherbotie JR: Collecting duct carcinoma arising in association with BK nephropathy post-transplantation in a pediatric patient. A case report with immunohistochemical and in situ hybridization study. Pediatr Transplant 2008;12:600-605.

12 Roberts ISD, Besaraani D, Mason P, Turner G, Friend PJ, Newton R: Polyoma virus infection and urothelial carcinoma of the bladder following renal transplantation. Br J Cancer 2008;99:1383-1386.

13 Wang HH, Liu KL, Chu SH, Tian YC, Lai PC, Chiang YJ: BK virus infection in association with posttransplant urothelial carcinoma. Transplant Proc 2009;41:165-166.

14 Chen CH, Wen MC, Wang M, Lian JD, Cheng CH, Wu MJ, Yu TM, Chuang YW, Chang D, Shu KH: High incidence of malignancy in polyomavirus-associated nephropathy in renal transplant recipients. Transplant Proc 2010;42:817-818.

15 Dalrymple SA, Beemon KL: BK virus T antigens induce kidney carcinomas and thymoproliferative disorders in transgenic mice. J Virol 1990;64:1182-1191.

16 Flaegstad T, Andersen P, Johnsen J, Asomani S, Jorgensen G, Vignagarajan S, Kjuul A, Kogner P: A possible contributory role of BK virus infection in neuroblastoma development. Cancer Res 1999;59:1160-1163.

17 Morath C, Mueller M, Goldschmidt H, Schwenger V, Opelz G, Zeier M: Malignancy in renal transplantation. J Am Soc Nephrol 2004;15:1582-1588.

18 Heejung K, Byung K, Chan K: Spontaneous regression of pulmonary and adrenal metastases following percutaneous radiofrequency ablation of a recurrent renal cell carcinoma. Korean J Radiol 2008;9:470472

19 Crisci A, Corsale I, Abrami F, Politi L, Andreani M, Borgianni S, Barale D, Porfirio B: Spontaneous regression of lung metastases from renal cell carcinoma: the importance of immunogenetic factors and a review of the literature. Minerva Urol Nefrol 2008;60:123-135.

-20 de Riese W, Goldenberg K, Allhoff E, Stief C, Schlick R, Liedke S, Jonas U: Metastatic renal cell carcinoma (RCC) spontaneous regression, long-term survival and later recurrence. Int Urol Nephrol 1991;23:1325 . 